\title{
The combination of ${ }^{13} \mathrm{~N}$-ammonia and
} ${ }^{11} \mathrm{C}$-methionine in differentiation of residual/ recurrent pituitary adenoma from the pituitary gland remnant after trans-sphenoidal Adenomectomy

Fangling Zhang ${ }^{1 \dagger}$, Qiao He ${ }^{2 \dagger}$, Ganhua Luo ${ }^{2}$, Yali Long ${ }^{2}$, Ruocheng Li ${ }^{2}$, Lei Ding ${ }^{2^{*}}$ and Xiangsong Zhang ${ }^{2^{*}}$

\begin{abstract}
Background: This study aimed to assess the clinical usefulness of ${ }^{13} \mathrm{~N}$-ammonia and ${ }^{11} \mathrm{C}$ - Methionine (MET) positron emission tomography (PET)/ computed tomography (CT) in the differentiation of residual/recurrent pituitary adenoma (RPA) from the pituitary gland remnant (PGR) after trans-sphenoidal adenomectomy.

Methods: Between June 2012 and December 2019, a total of 19 patients with a history of trans-sphenoidal adenomectomy before PET/CT scans and histological confirmation of RPA after additional surgery in our hospital were enrolled in this study. Images were interpreted by visual evaluation and semi-quantitative analysis. In semiquantitative analysis, the maximum standard uptake value (SUVmax) of the target and gray matter was measured and the target uptake/gray matter uptake (T/G) ratio was calculated.

Results: The T/G ratios of ${ }^{13} \mathrm{~N}$-ammonia were significantly higher in PGR than RPA (1.58 \pm 0.69 vs $0.63 \pm 1.37, P<$ 0.001 ), whereas the T/G ratios of ${ }^{11} \mathrm{C}-M E T$ were obviously lower in PGR than RPA $(0.78 \pm 0.35$ vs $2.17 \pm 0.54, P<$ 0.001). Using the canonical discriminant analysis, we calculated the predicted accuracy of RPA (100\%), PGR (92.9\%), and the overall predicted accuracy (96.43\%).

Conclusions: The combination of ${ }^{13} \mathrm{~N}$-ammonia and ${ }^{11} \mathrm{C}-\mathrm{MET}$ PET/CT is valuable in the differentiation of RPA from PGR after trans-sphenoidal adenomectomy.
\end{abstract}

Keywords: Residual/recurrent pituitary adenoma, Pituitary gland remnant, ${ }^{13} \mathrm{~N}$-ammonia, ${ }^{11} \mathrm{C}$-methionine, PET/CT

\footnotetext{
*Correspondence: dinglei3@mail.sysu.edu.cn; zhxiangs@mail.sysu.edu.cn

${ }^{\dagger}$ Fangling Zhang and Qiao He contributed equally to this work.

${ }^{2}$ Department of Medical Imaging, The First Affiliated Hospital, Sun Yat-sen

University, 58\#, Zhongshan Er Road, Guangzhou, Guangdong Province

510080, People's Republic of China

Full list of author information is available at the end of the article
}

(C) The Author(s). 2021 Open Access This article is licensed under a Creative Commons Attribution 4.0 International License, which permits use, sharing, adaptation, distribution and reproduction in any medium or format, as long as you give appropriate credit to the original author(s) and the source, provide a link to the Creative Commons licence, and indicate if changes were made. The images or other third party material in this article are included in the article's Creative Commons licence, unless indicated otherwise in a credit line to the material. If material is not included in the article's Creative Commons licence and your intended use is not permitted by statutory regulation or exceeds the permitted use, you will need to obtain permission directly from the copyright holder. To view a copy of this licence, visit http://creativecommons.org/licenses/by/4.0/. The Creative Commons Public Domain Dedication waiver (http://creativecommons.org/publicdomain/zero/1.0/) applies to the data made available in this article, unless otherwise stated in a credit line to the data. 


\section{Background}

The main treatment for primary pituitary adenomas is trans-sphenoidal surgery and residual/recurrent pituitary adenoma (RPA) can be seen in many patients [1-3]. Accurate localization of RPA and its differentiation from pituitary gland remnant (PGR) can promote targeted therapy, increase the remission rate and maximize the preservation of pituitary function. Postoperative magnetic resonance imaging (MRI), especially early reexamination, is difficult to interpret due to fluid, hemorrhage, and implanted material [4-6]. Methionine (MET), a substrate for ${ }^{11} \mathrm{C}$ labeling to trace increased protein synthesis, is a promising positron emission tomography (PET) tracer for the diagnosis of pituitary adenomas [7-9]. According to previous studies, ${ }^{11} \mathrm{C}-\mathrm{MET}$ was superior to somatostatin receptor (SSTR) ligand tracer and ${ }^{18}$ F-fluorodeoxyglucose (FDG) since pituitary adenomas are characterized by high amino acid metabolism [10-12]. Our research team previously reported that ${ }^{13} \mathrm{~N}$-ammonia was useful in identifying pituitary tissue [13, 14]. The main uptake mechanism is as follows: (1) metabolic trapping of ${ }^{13} \mathrm{~N}$-ammonia in pituitary tissue is related to the glutamine synthetase pathway (2) ${ }^{13} \mathrm{~N}$-ammonia is a good indicator of pituitary tissue blood flow. The purpose of this study was to retrospectively assess the usefulness of ${ }^{13} \mathrm{~N}$-ammonia and ${ }^{11} \mathrm{C}$-MET PET/ computed tomography $(\mathrm{CT})$ in the differentiation of RPA from PGR after trans-sphenoidal adenomectomy.

\section{Methods}

\section{Patients}

We retrospectively reviewed the data of suspected RPA (biological suggestion of active residual/recurrent tumor or MRI demonstration of nonfunctional pituitary adenoma) patients who underwent ${ }^{13} \mathrm{~N}$-ammonia and ${ }^{11} \mathrm{C}$ MET PET/CT scans in our center between June 2012 and December 2019. Patients who met the following requirements were included in this study:(1) a clinical history of trans-sphenoidal adenomectomy with histological confirmation before the PET/CT scan; (2) additional surgery after PET/CT imaging and pathological confirmation of RPA after the additional surgery; (3) the position of remaining pituitary tissue was confirmed during surgery or regular imaging and clinical follow-up for at least 1 year. Patients were excluded if they previously received radiation therapy, underwent surgical resection elsewhere or lost follow-up. Eventually a total of 19 patients (14 females and 5 males, mean age: $44.86 \pm 15.58$ years, range: $18-79$ years) were enrolled in this study and 14 of them were confirmed with PGR. Three patients were nonfunctional and 16 patients were hormone-secreting [ 9 patients produced adrenocorticotropic hormone $(\mathrm{ACTH}), 5$ patients produced prolactin
(PRL), 1 patient produced growth hormone $(\mathrm{GH})$, and 1 patient produced follicle-stimulating hormone (FSH)]. This study was approved by the hospital ethics committee and the need for signed informed consent was waived.

\section{Radiotracer synthesis and PET imaging protocol}

${ }^{13} \mathrm{~N}$-ammonia and ${ }^{11} \mathrm{C}$-MET were produced in our department by commercially available systems for isotope generation (Ion Beam Applications, Cyclone-10, Belgium) with standard methods. The radiochemical purity was $>99 \%$. PET/CT scans were performed with a Gemini GXL-16 scanner (Philips, Netherlands). Five minutes after intravenous injection of $7.4 \mathrm{MBq}(0.20 \mathrm{mCi}) /$ $\mathrm{kg}{ }^{13} \mathrm{~N}$-ammonia or ${ }^{11} \mathrm{C}$-MET, a 10 -min serial PET/CT scan using a brain imaging protocol (matrix: $128 \times 128$ pixels; slice thickness: $1.5 \mathrm{~mm}$; FOV: $180 \mathrm{~mm}$ ) was initiated. Images were attenuation-corrected with low-dose CT and reconstructed with the Line of Response RAMLA algorithm. ${ }^{13} \mathrm{~N}$-ammonia and ${ }^{11} \mathrm{C}$-MET PET/ CT were performed with an interval of at least $24 \mathrm{~h}$.

\section{Imaging analysis}

PET images were interpreted by two experienced nuclear physicians independently and reached a consensus.

\section{Visual analysis}

The uptake of the targets was classified into 3 degrees visually compared to the surrounding normal brain tissue: low uptake, moderate uptake, and high uptake. Moderate and high uptake on ${ }^{11} \mathrm{C}$-MET PET/CT images was considered positive.

\section{Semi-quantitative analysis}

For each patient, a region of interest (ROI) over the entire target was drawn on the transaxial plane referred to MRI or computerized tomography (CT) images, and the maximum standardized uptake value (SUVmax) was measured. Then another referenced ROI (approximately $10 \mathrm{~mm}$ in diameter) was drawn on the normal gray matter of the left prefrontal cortex, gaining the target uptake/gray matter uptake (T/G) ratio.

\section{Statistical analysis}

Statistical analysis was performed using SPSS 20.0 software (IBM SPSS statistics 20.0, Armonk, NY, USA). Measurement data were expressed in form of mean \pm standard deviation (SD). First, the T/G ratios of RPA and PGR were compared using Student's $t$-test for each tracer. Second, the $\mathrm{T} / \mathrm{G}$ ratios of the two tracers were adopted as multiple variables in the canonical discrimination analysis. By obtaining the canonical discriminant function, each patient could be successfully classified into one group according to the functional result. 
Finally, cross validation was performed. $P<0.05$ suggested that difference had statistical significance.

\section{Results}

PGR was identified in 14 patients with PET and could not be identified by any other imaging modality in 5 patients. Of the 14 patients, 8 were determined to have normal function, and 6 were determined to have hypopituitarism. The diameter of RPA ranged from 1.0 to 4.2 $\mathrm{cm}(1.83 \pm 0.73 \mathrm{~cm})$.

\section{Result of visual analysis}

For the 19 patients with RPA, 14 (73.68\%), 3(15.79\%), $2(10.53 \%)$ patients were graded as low, moderate, and high uptake respectively on ${ }^{13} \mathrm{~N}$-ammonia PET images and 1 (5.26\%), 18 (94.74\%) patients were graded as low and high uptake respectively on ${ }^{11} \mathrm{C}$-MET PET images.

For the 14 patients with PGR, 2 (14.29\%), 12 (85.71\%) patients were graded as moderate and high uptake respectively on ${ }^{13} \mathrm{~N}$-ammonia PET images and 8 (57.14\%), $5(35.71 \%), 1$ (7.14\%) patients were graded as low, moderate and high uptake respectively on ${ }^{11} \mathrm{C}$-MET PET images.

Of the 19 patients with RPA, MET was positive in 18 patients (18 true positive) and negative in 1 patient (1 false negative; tumor type: $\mathrm{ACTH}$ ) compared to histological results.

\section{Result of semi-quantitative analysis}

The $\mathrm{T} / \mathrm{G}$ ratios of ${ }^{13} \mathrm{~N}$-ammonia were significantly higher in PGR than RPA $(1.58 \pm 0.69$ vs $0.63 \pm 1.37, P<$ 0.001 ), however, the $\mathrm{T} / \mathrm{G}$ ratios of ${ }^{11} \mathrm{C}$-MET were obviously lower in PGR than RPA $(0.78 \pm 0.35$ vs $2.17 \pm 0.54$, $P<0.001$ ) (Figs. 1, 2 and 3). Canonical discriminant analysis with 14 patients whose PRA could be identified showed that the optimal discriminant function was $\mathrm{F}(\mathrm{x}$, $y)=-0.814 x+1.820 y-1.788$, where $x$ represented a $T /$ $\mathrm{G}$ ratio of ${ }^{13} \mathrm{~N}$-ammonia and y represented a $\mathrm{T} / \mathrm{G}$ ratio of ${ }^{11} \mathrm{C}$-MET. The functional result of RPA was $1.65 \pm$ 1.03 , which was higher than that of PGR $(-1.65 \pm 0.97$, $P<0.001)$. The predicted accuracy of RPA $(100 \%)$, PGR (92.9\%) and the overall predicted accuracy $(96.43 \%)$ were calculated. As a result, only 1 PGR was misdiagnosed as RPA (Table 1, Fig. 4).

\section{Discussion}

For patients after trans-sphenoidal pituitary adenomectomy, postoperative follow-up by clinical and imaging methods remains necessary. To our knowledge, MRI is an excellent imaging modality and the top choice in the assessment of pituitary lesions. However, considering the morphological changes of the postoperative area and the confusion about the anatomical structures, MRI is often unable to distinguish RPA from PGR $[4-6,15]$. In addition, RPA is particularly more difficult to detect by

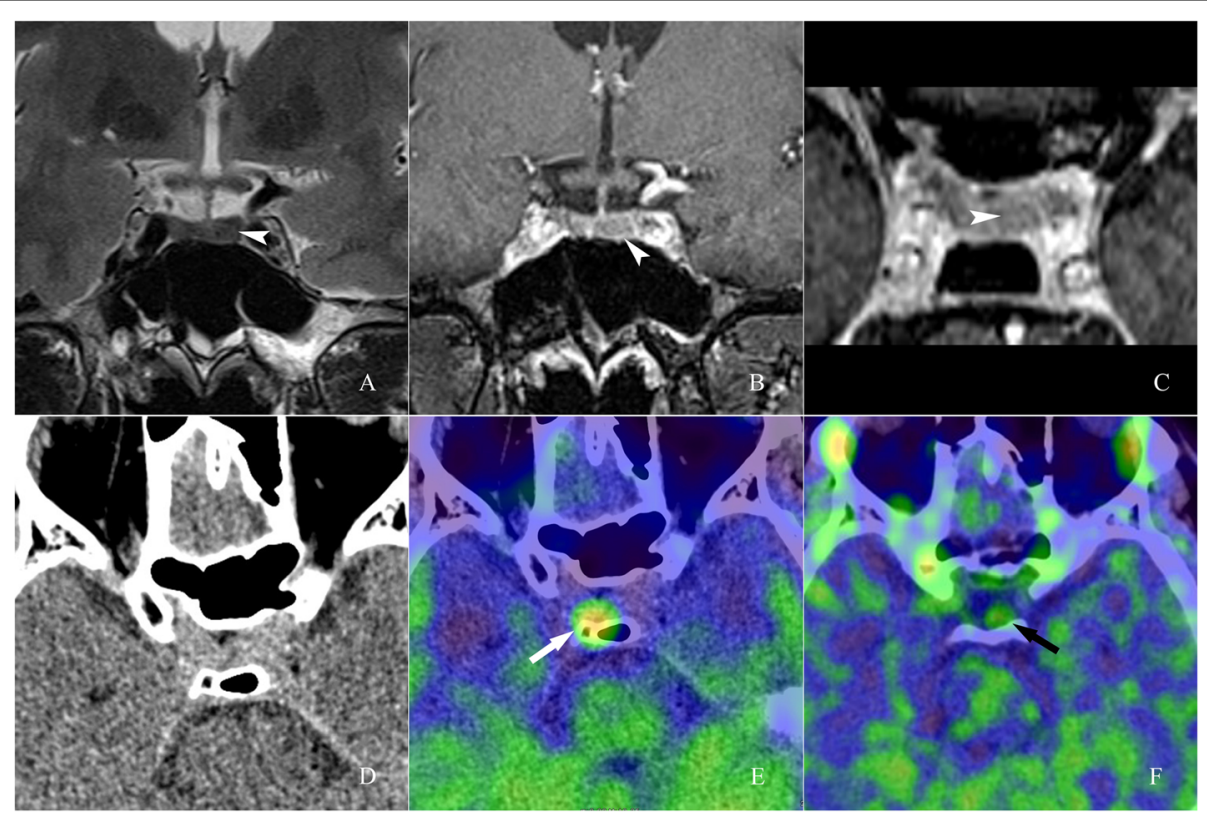

Fig. 1 Images of a 20-year-old man with recurrent adrenocorticotropic hormone (ACTH)-secreting pituitary adenoma. A (T2-weighted coronal image), B (T1-weighted contrast-enhanced coronal image) and C (T1-weighted contrast-enhanced axial image) showed a suspicious equisignal lesion in the left part of the sella on plane and enhanced images (arrowhead). A PET/CT scan was recommended by clinician. On ${ }^{13} \mathrm{~N}$-ammonia PET/CT, a hypermetabolic region in the right part of the sella was observed, revealing the pituitary gland remnant with normal function (E, white arrow). On ${ }^{11} \mathrm{C}-\mathrm{MET}$ PET/CT, a moderate-metabolic region in the left part of the sella was observed, revealing the recurrent adenoma ( $\mathrm{F}$, black arrow) 


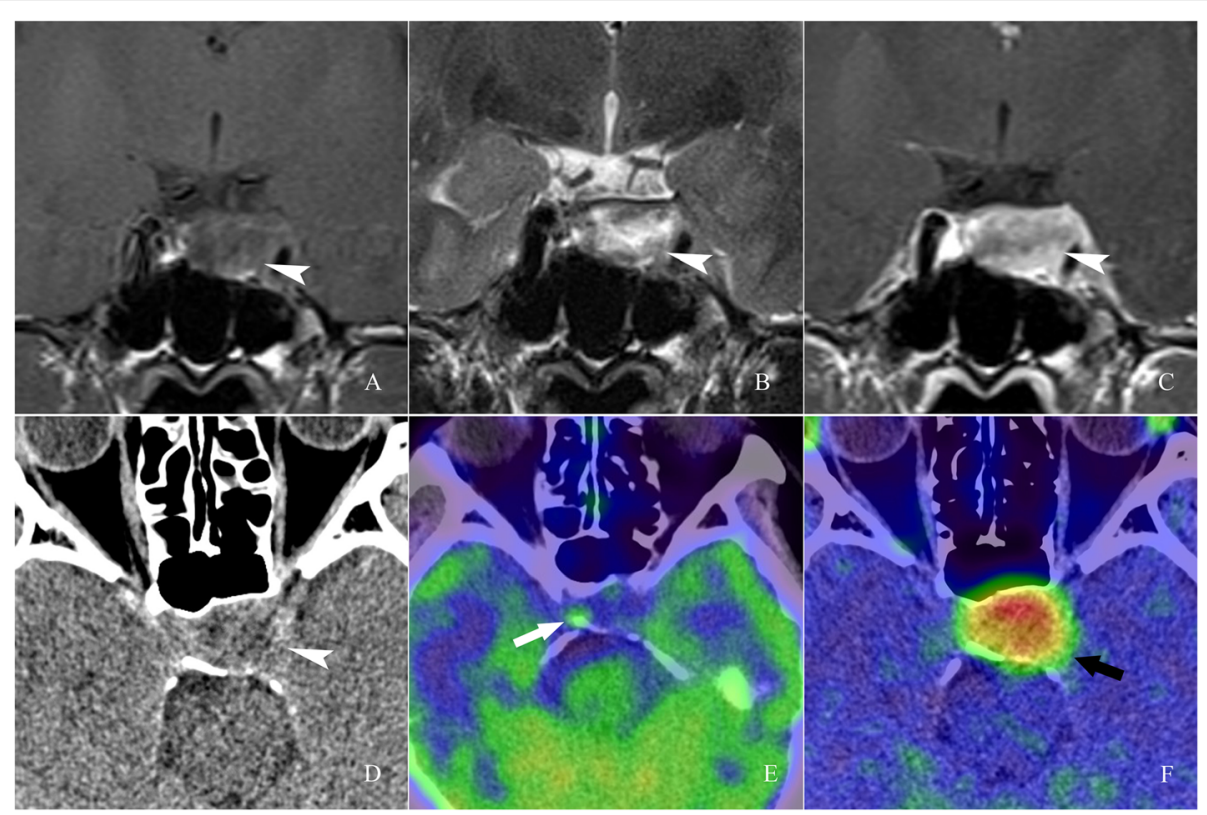

Fig. 2 Images of a 37-year-old woman with recurrent prolactin (PRL)-secreting pituitary adenoma. T1-weighted coronal image, T2-weighted coronal image and T1-weighted contrast-enhanced coronal image showed an adenoma in the sella (A, B, C arrowhead). On ${ }^{13} \mathrm{~N}$-ammonia PET/CT, a moderate-metabolic region in the right part of the sella was observed, revealing the pituitary gland remnant with hypopituitarism (E, white arrow). On ${ }^{11} \mathrm{C}-\mathrm{MET}$ PET/CT, an extreme hypermetabolic region in the the sella was observed, which was consistent with the CT and MRI images (F, black arrow)

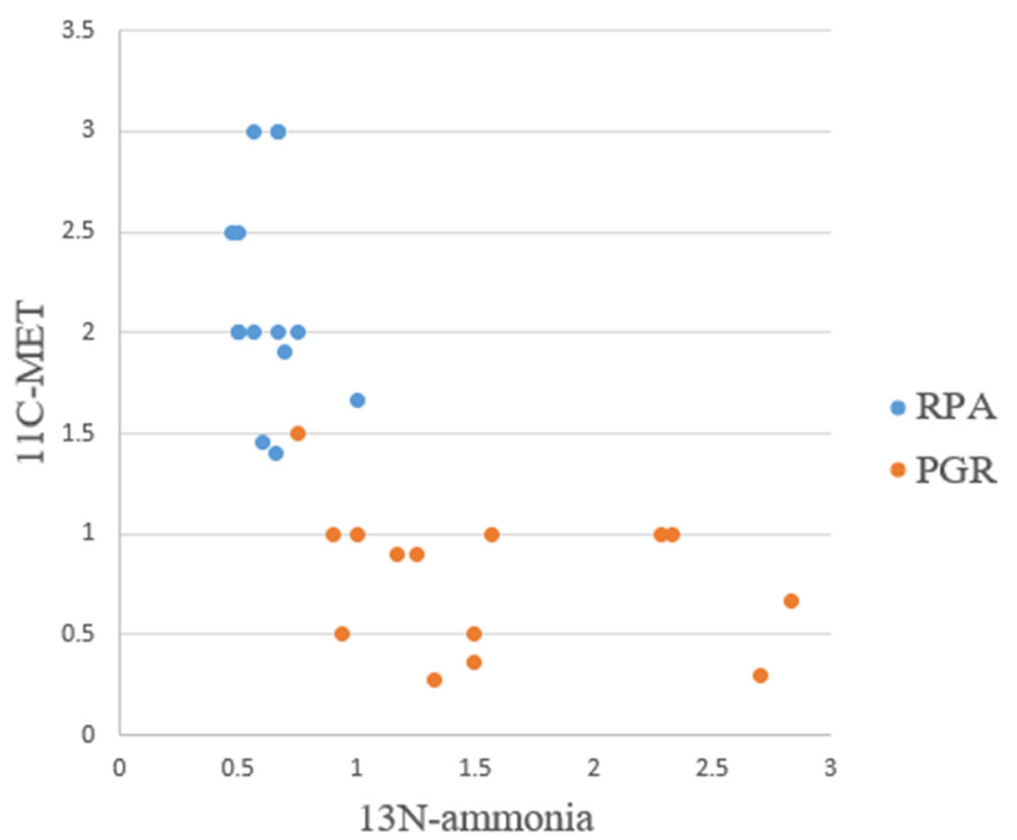

Fig. 3 Distribution map of T/G ratios of ${ }^{13} \mathrm{~N}$-ammonia and ${ }^{11} \mathrm{C}-\mathrm{MET}$. As shown in this figure, a small overlap was observed between RPA (blue spot) and PGR (red spot) 
Table 1 Predicted accuracy of the 2 groups by discriminant analysis

\begin{tabular}{|c|c|c|c|c|c|}
\hline & \multicolumn{4}{|c|}{ Predicted Group Membership } \\
\hline & & Group & RPA & PGR & Total \\
\hline \multirow[t]{2}{*}{ Original } & $\mathrm{n}(\%)$ & RPA & $14(100)$ & $0(100)$ & $14(100)$ \\
\hline & & $P G R$ & $1(100)$ & $13(100)$ & $14(100)$ \\
\hline \multirow[t]{2}{*}{ Cross-validated } & n (\%) & RPA & $14(100)$ & $0(100)$ & 14 \\
\hline & & PGR & $1(100)$ & $13(100)$ & $14(100)$ \\
\hline
\end{tabular}

MRI given its smaller size compared with the primary tumor $[6,16]$. PET is a complementary imaging technique for pituitary adenoma evaluation with different tracers [17]. As the most commonly used PET tracer, ${ }^{18}$ F-FDG was described to be unsatisfactory in the diagnosis of pituitary adenomas (especially recurrent cases), probably because FDG uptake is related to tumor malignancy or aggressiveness rather than hormonal production and secretion $[18,19]$. Its utility is also limited by low sensitivity and high uptake in surrounding normal brain tissue.

In our study, ${ }^{13} \mathrm{~N}$-ammonia demonstrated higher uptake in PGR than RPA and ${ }^{11} \mathrm{C}$-MET had higher uptake in RPA compared with PGR. Thus, ${ }^{13} \mathrm{~N}$-ammonia PET played a better role in the identification of PGR, whereas ${ }^{11} \mathrm{C}$-MET PET seems more useful in the detection of RPA.
${ }^{13} \mathrm{~N}$-ammonia is not only a good indicator of the blood flow of the pituitary gland, but also a potential tracer to indicate glutamine synthesis metabolism, as reported in our previous studies [20-22]. Pituitary tissue exhibited significantly high uptake of ${ }^{13} \mathrm{~N}$-ammonia due to the absence of the blood-brain barrier (BBB), high regional cerebral blood flow $(\mathrm{CBF})$, and high capillary permeability surface area product [22]. Glutamine synthetase (GS) is a catalyst in the glutamine synthesis reaction and its activity was confirmed in the anterior lobe of the pituitarium [23] As for displaying the position of pituitary tissue, the ability of ${ }^{13} \mathrm{~N}$-ammonia is comparable to MRI [14]. Even in some cases, ${ }^{13} \mathrm{~N}$-ammonia could exhibit potential value when MRI findings were negative. Besides, ${ }^{13} \mathrm{~N}$-ammonia is also a promising imaging method to reflect the pituitary function. Hypopituitarism showed decreased ${ }^{13} \mathrm{~N}$-ammonia uptake and could be diagnosed in the early stage [13]. In our study, 14 patients were identified with PGR $(14 / 14)$ on ${ }^{13} \mathrm{~N}$-ammonia images.

The usefulness of ${ }^{11} \mathrm{C}$-MET PET/CT in identifying pituitary tumors has been reported in previous studies $[10,11$, 24]. Furthermore, BNT Tang and ZZ Feng reported a high positive rate of ${ }^{11} \mathrm{C}$-MET PET/CT in recurrent adenomas regardless of the tumor size and the endocrine subgroups $[8,10]$, contributing to the efficient management of tumors. RPA was characterized by high amino acid

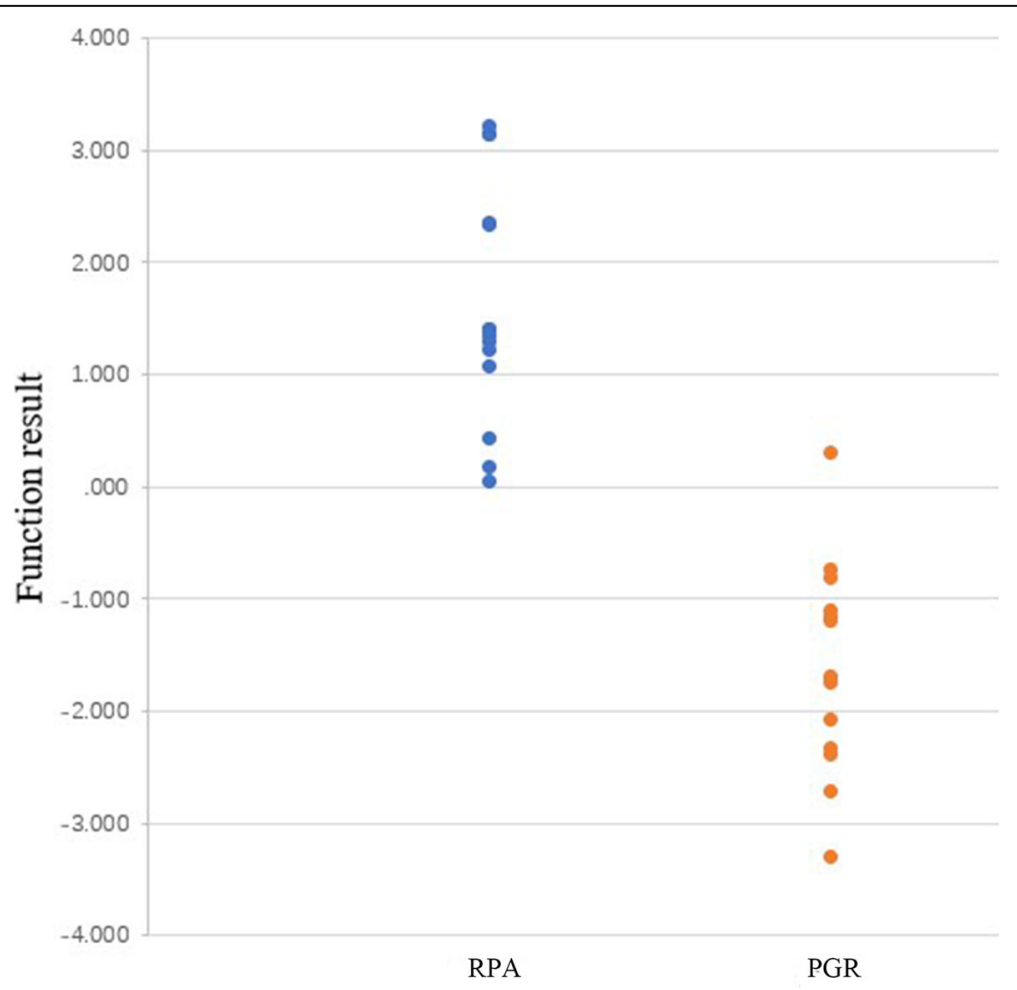

Fig. 4 Discriminant function results of the two groups. The functional results of RPA were obviously higher than that of PGR (1.65 \pm 1.03 Vs $1.65 \pm 0.97)$. The combination of the two tracers could distinguish these two clinical entities effectively 
metabolism. The detection rate of ${ }^{11} \mathrm{C}$-MET was very high in this investigation for RPA (18/19), even in nonfunctional adenomas, which was in accordance with previous studies $[8,10,11]$. Only one patient showed low uptake of ${ }^{11} \mathrm{C}$-MET due to extensive cystic degeneration within the tumor. Conversely, PGR showed minimal uptake on ${ }^{11} \mathrm{C}$ MET images. Sex, age, and the menstrual cycle in women can influence the accumulation of ${ }^{11} \mathrm{C}$-MET in the remaining pituitary tissue. Occasionally, the ${ }^{11} \mathrm{C}$-MET uptake in pituitary gland can be confused and result in false positive results. Besides, RPA is not always identified with high uptake because of necrosis, cystic degeneration and hemorrhage. To avoid this phenomenon, another imaging comparison has been suggested to identify residual pituitary tissue [25]. We selected ${ }^{13} \mathrm{~N}$-ammonia to locate the pituitary gland based on our previous studies [13, 20-22]. When ${ }^{13} \mathrm{~N}$-ammonia was combined with ${ }^{11} \mathrm{C}$-MET, the differential accuracy of these 2 clinical entities was $96.43 \%$. By accurately locating RPA and PGR, ${ }^{13} \mathrm{~N}$-ammonia and ${ }^{11} \mathrm{C}$-MET PET can guide surgery and realize the maximal protection of pituitary function. ${ }^{68} \mathrm{Ga}$ 1,4,7,10-tetraazacyclododecane- $\mathrm{N}, \mathrm{N}^{\prime}, \mathrm{N}^{\prime \prime}$, N"'-tetraacetic acid-D-Phe1, Tyr3-octreotate (DOTATATE), a novel somatostatin analog, can also be applied in the recognition of remaining pituitary tissue. The accumulation was only lower than that in spleen, kidneys, and adrenal glands [26, 27]. However, limited information has been reported so far. Further studies are needed to explore the efficacy of ${ }^{68} \mathrm{Ga}$ DOTATATE.

One major limitation of the study is that we did not provide the uptake information of scar tissue. Scar tissue may form at the post-operative site, particularly after graft implantation. Although the scar tissue should have no or minimal metabolism as predicted in previous study [5], caution is warranted to interpret it. Then, we were not able to make comparison of conventional MRI and PET in the differentiation of RPA and PGA because not every patient underwent MRI scan in our hospital. Future study should be performed on this problem.

\section{Conclusions}

The combination of ${ }^{13} \mathrm{~N}$-ammonia and ${ }^{11} \mathrm{C}$-MET PET/ $\mathrm{CT}$ is valuable in the differentiation of RPA from PGR after trans-sphenoidal adenomectomy.

\footnotetext{
Abbreviations

RPA: Residual/recurrent pituitary adenoma; PGR: Pituitary gland remnant; MRI: Magnetic resonance imaging; MET: Methionine; SSTR: Somatostatin receptor; ${ }^{18} \mathrm{~F}$-FDG: ${ }^{18} \mathrm{~F}$-fluorodeoxyglucose; GH: Growth hormone; ACTH: Produced adrenocorticotropic hormone; FSH: Follicle-stimulating hormone; ROI: Region of interest; CT: Computerized tomography; SUVmax: Maximum standardized uptake value; BBB: Blood brain barrier; CBF: Cerebral blood flow; GS: Glutamine synthetase; DOTATATE: Etraazacyclododecane-N, N', N", N"'-tetraacetic acid-D-Phe1, Tyr3octreotate
}

\section{Acknowledgements}

Not applicable.

\begin{abstract}
Authors' contributions
FLZ and QH participated in the design of the study, collected the patients data, and drafted the manuscript. GHL, YLL and RCL processed the figures, helped draft the manuscript, and performed a critical revision of the manuscript. XSZ and LD conceived and designed the study and supervised the project. All authors read and approved the final version of the manuscript.
\end{abstract}

\section{Funding}

There was no funding for this study.

\section{Availability of data and materials}

The dataset supporting the conclusions of this article is included within the article. Data and materials during the current study are available from the corresponding author upon reasonable request.

\section{Declarations}

Ethics approval and consent to participate

The study was approved by the Institutional Ethics Committee of the First Affiliated Hospital of Sun Yat-Sen University, and the need for signed informed consent was waived. All the authors confirm that all methods were carried out in accordance with relevant guidelines and regulations.

\section{Consent for publication}

Not applicable.

\section{Competing interests}

The authors declare that they have no competing interests.

\section{Author details}

${ }^{1}$ Department of Radiology, Hospital of Stomatology, Guanghua School of Stomatology, Sun Yat-sen University \& Guangdong Provincial Key Laboratory of Stomatology, 56\#, Cemetery west Road, Guangzhou, Guangdong Province 510055, People's Republic of China. ${ }^{2}$ Department of Medical Imaging, The First Affiliated Hospital, Sun Yat-sen University, 58\#, Zhongshan Er Road, Guangzhou, Guangdong Province 510080, People's Republic of China.

Received: 1 March 2021 Accepted: 7 July 2021

Published online: 20 July 2021

\section{References}

1. Losa M, Mortini P, Barzaghi R, Gioia L, Giovanelli M. Surgical treatment of prolactin-secreting pituitary adenomas: early results and long-term outcome. J Clin Endocrinol Metab. 2002;87(7):3180-6. https://doi.org/10.121 0/jcem.87.7.8645.

2. Jaffe CA. Clinically non-functioning pituitary adenoma. Pituitary. 2006:9(4): 317-21. https://doi.org/10.1007/s11102-006-0412-9.

3. Esposito V, Santoro A, Minniti G, Salvati M, Innocenzi G, Lanzetta G, et al. Trans-sphenoidal adenomectomy for GH-, PRL- and ACTH-secreting pituitary tumours: outcome analysis in a series of 125 patients. Neurol Sci. 2004;25(5): 251-6. https://doi.org/10.1007/s10072-004-0351-z.

4. Kremer P, Forsting M, Hamer J, Sartor K. MR imaging of residual tumor tissue after trans-sphenoidal surgery of hormone-inactive pituitary macroadenomas: a prospective study. Acta Neurochir Suppl. 1996;65:27-30. https://doi.org/10.1007/978-3-7091-9450-8_9.

5. Sumida M, Uozumi T, Mukada K, Arita K, Kurisu K, Yano T, et al. MRI of pituitary adenomas: the position of the normal pituitary gland. Neuroradiology. 1994;36(4):295-7. https://doi.org/10.1007/BF00593264.

6. Kremer P, Forsting M, Ranaei G, Wüster C, Hamer J, Sartor K, et al. Magnetic resonance imaging after trans-sphenoidal surgery of clinically non-functional pituitary macroadenomas and its impact on detecting residual adenoma. Acta Neurochir. 2002;144(5):433-43. https://doi.org/10.1007/s007010200064.

7. Muhr C. Positron emission tomography in acromegaly and other pituitary adenoma patients. Neuroendocrinology. 2006;83(3-4):205-10. https://doi. org/10.1159/000095529. 
8. Tang BN, Levivier M, Heureux M, et al. 11C-methionine PET for the diagnosis and management of recurrent pituitary adenomas. Eur J Nucl Med Mol Imaging. 2006;33(2):169-78. https://doi.org/10.1007/s00259-005-1882-0.

9. Bergström $M$, Muhr C, Lundberg PO, Långström B. PET as a tool in the clinical evaluation of pituitary adenomas. J Nucl Med. 1991;32(4):610-5.

10. Feng Z, He D, Mao Z, et al. Utility of 11C-methionine and 18F-FDG PET/CT in patients with functioning pituitary adenomas. Clin Nucl Med. 2016;41(3): e130-4. https://doi.org/10.1097/RLU.0000000000001085.

11. Koulouri O, Steuwe A, Gillett D, et al. A role for $11 \mathrm{C}$-methionine PET imaging in ACTH-dependent Cushing's syndrome. Eur J Endocrinol. 2015;173(4):M107-20. https:/doi.org/10.1530/EJE-15-0616.

12. Rodriguez-Barcelo S, Gutierrez-Cardo A, Dominguez-Paez M, MedinaImbroda J, Romero-Moreno L, Arraez-Sanchez M. Clinical usefulness of coregistered $11 \mathrm{C}$-methionine positron emission tomography/3-T magnetic resonance imaging at the follow-up of acromegaly. World Neurosurg. 2014; 82(3-4):468-73. https://doi.org/10.1016/j.wneu.2013.11.011.

13. Xiangsong Z, Xinjian W, Yong Z, Weian C. 13N-NH3: a selective contrastenhancing tracer for brain tumor. Nucl Med Commun. 2008;29(12):1052-8. https://doi.org/10.1097/MNM.0b013e328310af34.

14. Wang Z, Mao Z, Zhang X, et al. Utility of 13N-Ammonia PET/CT to detect pituitary tissue in patients with pituitary adenomas. Acad Radiol. 2019;26(9): 1222-8. https://doi.org/10.1016/j.acra.2018.09.015.

15. Ikeda H, Abe T, Watanabe K. Usefulness of composite methionine-positron emission tomography/3.0-tesla magnetic resonance imaging to detect the localization and extent of early-stage Cushing adenoma. J Neurosurg. 2010; 112(4):750-5. https://doi.org/10.3171/2009.7.JNS09285.

16. Di Maio S, Biswas A, Vézina JL, Hardy J, Mohr G. Pre- and postoperative magnetic resonance imaging appearance of the normal residual pituitary gland following macroadenoma resection: clinical implications. Surg Neurol Int. 2012;3:67.

17. Iglesias P, Cardona J, Díez JJ. The pituitary in nuclear medicine imaging. Eur J Intern Med. 2019;68:6-12. https://doi.org/10.1016/j.ejim.2019.08.008.

18. De Souza B, Brunetti A, Fulham MJ, et al. Pituitary microadenomas: a PET study. Radiology. 1990;177(1):39-44. https:/doi.org/10.1148/radiology.177.1.2399336.

19. Chittiboina P, Montgomery BK, Millo C, Herscovitch P, Lonser RR. High-resolution (18) F-fluorodeoxyglucose positron emission tomography and magnetic resonance imaging for pituitary adenoma detection in Cushing disease. J Neurosurg. 2015; 122(4):791-7. https:/doi.org/10.3171/2014.10.JNS14911.

20. Shi X, Zhang $X$, Yi C, Liu Y, He Q. $\left.{ }^{[3} \mathrm{N}\right]$ Ammonia positron emission tomographic/computed tomographic imaging targeting glutamine synthetase expression in prostate cancer. Mol Imaging. 2014;13. https://doi. org/10.2310/7290.2014.00048.

21. He Q, Shi X, Zhang L, Yi C, Zhang X, Zhang X. De novo glutamine synthesis: importance for the proliferation of glioma cells and potentials for its detection with 13N-Ammonia. Mol Imaging. 2016;15:153601211664544. https://doi.org/10.1177/1536012116645440.

22. Ding $L$, Zhang $F, H e ~ Q$, et al. Differentiation of suprasellar meningiomas from non-functioning pituitary macroadenomas by $18 \mathrm{~F}-\mathrm{FDG}$ and $13 \mathrm{~N}-$ Ammonia PET/CT. BMC Cancer. 2020;20(1):564. https://doi.org/10.1186/s12 885-020-06852-y.

23. Shirasawa N, Yamanouchi H. Glucocorticoids induce glutamine synthetase in folliculostellate cells of rat pituitary glands in vivo and in vitro. J Anat. 1999;194(Pt 4):567-77. https://doi.org/10.1046/.1469-7580.1999.19440567.x.

24. Koulouri $\mathrm{O}$, Kandasamy N, Hoole AC, et al. Successful treatment of residual pituitary adenoma in persistent acromegaly following localisation by 11Cmethionine PET co-registered with MRI. Eur J Endocrinol. 2016;175(5):48598. https://doi.org/10.1530/EJE-16-0639.

25. Xiangsong Z, Dianchao Y, Anwu T. Dynamic $13 \mathrm{~N}$-ammonia PET: a new imaging method to diagnose hypopituitarism. J Nucl Med. 2005;46(1):44-7.

26. Zhao X, Xiao J, Xing B, Wang R, Zhu Z, Li F. Comparison of (68) Ga DOTATATE to 18 F-FDG uptake is useful in the differentiation of residual or recurrent pituitary adenoma from the remaining pituitary tissue after transsphenoidal adenomectomy. Clin Nucl Med. 2014;39(7):605-8. https://doi. org/10.1097/RLU.0000000000000457.

27. Kuyumcu S, Özkan ZG, Sanli Y, et al. Physiological and tumoral uptake of (68) Ga-DOTATATE: standardized uptake values and challenges in interpretation. Ann Nucl Med. 2013;27(6):538-45. https://doi.org/10.1007/ s12149-013-0718-4.

\section{Publisher's Note}

Springer Nature remains neutral with regard to jurisdictional claims in published maps and institutional affiliations.

Ready to submit your research? Choose BMC and benefit from:

- fast, convenient online submission

- thorough peer review by experienced researchers in your field

- rapid publication on acceptance

- support for research data, including large and complex data types

- gold Open Access which fosters wider collaboration and increased citations

- maximum visibility for your research: over $100 \mathrm{M}$ website views per year

At BMC, research is always in progress.

Learn more biomedcentral.com/submissions 